\title{
PEMANFAATAN DEBAT KANDIDAT UNTUK MENJUAL GAGASAN DAN MENUNJUKKAN KOMPETENSI DALAM PILKADA 2015 DI KABUPATEN SOPPENG
}

\section{The Use of Candidates Debate to Promote the Ideas and Competence in the Election in 2015 in Soppeng Regency}

\author{
${ }^{1}$ Andi Syadaruddin, ${ }^{2}$ Muh. Iqbal Sultan, ${ }^{3}$ Hasrullah \\ ${ }^{1}$ Jurusan Ilmu Komunikasi, Fakultas Ilmu Sosial dan Ilmu Politik, \\ Universitas Hasanuddin, Makassar (andi.syahdar76@gmail.com) \\ ${ }^{2}$ Jurusan Ilmu Komunikasi, Fakultas Ilmu Sosial dan Ilmu Politik, \\ Universitas Hasanuddin, Makassar (miqsul@yahoo.com) \\ ${ }^{3}$ Jurusan Ilmu Komunikasi, Fakultas Ilmu Sosial dan Ilmu Politik, \\ Universitas Hasanuddin, Makassar (has_ullah@yahoo.com)
}

\begin{abstract}
ABSTRAK
Pemilihan kepala daerah merupakan arena kontestasi politik dengan kompetisi antar pasangan kandidat, dan pemenang ditentukan suara terbanyak oleh pemilih. Penelitian ini bertujuan untuk mengetahui pemanfaatan debat kandidat sebagai sarana menyampaikan pesan-pesan politik dengan cara public speaking dan mengetahui penguasaan materi dengan tujuan mempersuasi khalayak serta membangun opini publik. Jenis penelitian ini adalah deskriptif Kualitatif. Informan penelitian ini adalah para kandidat pasangan calon, Tim Sukses, dan KPU Kabupaten Soppeng. Penetapan informan dalam penelitian ini menggunakan dua cara yaitu purposif dan aksidental. Pengumpulan data dilakukan melalui observasi wawancara dan dokumentasi. Hasil penelitian menunjukkan bahwa kedua kandidat calon Bupati Soppeng, tidak pernah mengikuti pelatihan public speaking. Menyusun materi debat pada dasarnya hasil olah pikir dan ide dari berbagai pihak termasuk dari masyarakat sebagai bentuk penggalangan aspirasi. Materi debat yang sifatnya untuk mempersuasi khalayak yang berisi pesan-pesan yang bertujuan untuk mempengaruhi pendapat dan perilaku khalayak. Kekuatan dari materi debat, yaitu dapat memberikan informasi tentang kandidat kepada khalayak. Kredibilitas pasangan calon Bupati dan Wakil Bupati Soppeng terbangun atas kualitas dan kapasitas atau kekuatan untuk menimbulkan kepercayaan. Kualitas harus dibangun sejak awal, yaitu berupa pengalaman dan pengetahuan.para kandidat termotivasi untuk mempersuasi khalayak adalah untuk mendorong dan mengugah partisipasinya dalam pilkada, serta bahwa audiens merupakan pemilih cerdas yang akan membantu secara sukarela mendukung kandidat tertentu.
\end{abstract}

Kata kunci : debat kandidat, pilkada, public speaking, karakter, kompetensi, Kabupaten Soppeng

\section{ABSTRACT}

The local elections is an arena of political contestation with competition between pairs of candidates, and the winner is determined by a majority vote of voters. This study aims to analyze the use of the candidat debates as a means of conveying political messages through public speaking, as well as mastery of the material that aims to persuade public and build public opinion. This research was a descriptive qualitative study. The informants were the candidates, Success Team, and the Election Commission Soppeng Regency. The informants were selected trought purposive and accidential methods. Data collection instruments were observation, interviews and documentation. The results showed that both Regent candidates of Soppeng Regency have never taken public speaking training. The debate matter preparation is basically the result of a thought and ideas from various parties, including the society as a form of aspiration raising. The debates material that are aimed to persuade the people containing messages to influence people's opinion and behavior. The strength of the material is to provide information about the candidates. The credibility of the candidate pairs of Regent and Vice Regent Soppeng is built upon the quality and the capacity or 
power to generate trust. Quality must be built from the very beginning of the process, in the form of experience and knowledge. The candidates are motivated to persuade the audience is to encourage and inspire participation in the elections, and that the audience is intelligent voters who will volunteer to support a particular candidate.

Keywords: debates, elections, public speaking, character, competence, Soppeng Regency

\section{PENDAHULUAN}

Debat dipandang sebagai inovasi dalam kampanye komunikasi. Debat terbuka antar kandidat mungkin terbukti paling signifikan karena khalayak mampu menilai kualitas calon pimpinan lokal, sekaligus ajang para kandidat untuk menarik simpatisan atau mencari dukungan publik. Kaid (2015), memaparkan bahwa pembenaran yang paling sering dikutip untuk studi tentang debat adalah kenyataan mereka menjangkau audiens yang lebih banyak - lebih dari semua acara kampanye.

Pengaruh partai sebagai mesin politik, melahirkan atau merekrut kandidat guna meraih suara dalam pesta demokrasi seperti pilkada. Dengan menampilkan politikus cerdas dan integritas yang andal akan berkolaborasi dengan visi misi dan program kerja yang jitu dalam menaikkan jumlah dukungan. Politisi profesional tentu sangat piawai dalam melakukan manuver politik yang tentunya taat dan patuh pada etika politik (Hasrullah, 2014).

Kandidat sebagai komunikator politik menyampaikan pesan-pesan politik yang tentunya harus menghidari distorsi informasi yang diungkapkan dalam komunikasi verbal dan non-verbal dengan cara-cara public speaking. Menurut Pabottingi dalam Rauf et al (1993), menjelaskan bahwa distorsi dalam komunikasi politik dapat terjadi khususnya dari segi bahasa. Kampanye dialogis termasuk debat, membuka ruang dan pikiran publik bahwa politikus semakin dituntut memiliki "public speaking" dan mengajukan gagasan kepada publik dengan baik. Pada era munculnya pemimpin yang dikenal fasih dalam berbicara di depan umum, mereka dikenal mampu mempersuasi massa melalui kemahiran komunikasi lisannya.

Dance dalam Littlejohn et al (2014), memberikan definisi komunikasi adalah suatu sistem untuk menyampaikan informasi dan perintah bersifat membatasi. Begitu pula yang kemukakan oleh John B. Hoben dalam Mulyana (2014), komunikasi adalah pertukaran verbal pikiran atau gagasan secara berhasil ditukarkan.
Menurut Mulyana (2014), menyatakan bahwa definisi yang dikemukakan oleh Harold D. Lasswell, dianggap sebagai salah satu model utama dari komunikasi politik yang bersifat linier. Sedangkan menurut Dahlan dalam Cangara (2014), ialah suatu bidang atau disiplin yang menelaah perilaku dan kegiatan komunikasi yang bersifat politik, mempunyai akibat atau berpengaruh terhadap perilaku politik. Komunikator politik merupakan orang yang menduduki posisi dan peka terhadap jaringan sosial, menanggapi dan menolak berbagai tekanan serta memilih informasi yang semua terjadi dalam sistem sosial yang bersangkutan (Subiakto, 2014).

Membicarakan pesan (massage) dalam proses komunikasi, tidak bisa lepas dari apa yang disebut simbol dan kode, karena pesan yang dikirim komunikator kepada penerima terdiri atas rangkaian simbol dan kode. Setiap bahasa memiliki pola yang dapat diidentifikasi dan menetapkan aturan relative (Ruben, 2013). Seperti yang diungkapkan oleh Berlo dalam Cangara (2015), bahwa sebuah simbol tidak memiliki arti bukanlah kode. Pesan biasanya berisikan tentang gagasan atau ide komunikator untuk disampaikan bahkan untuk diperbincangkan dengan penerima (komunikan). Ragam pesan bisa berbentuk verbal dan nonverbal.

Berbicara di depan umum, berbicara di depan publik atau pembicaraan publik, merupakan istilah yang mewakili sebutannya "public speaking". Menurut Webster's Third New International Dictionary dalam Hidajat (2006), mengartikan public speaking sebagai proses penyampaian pembicaraan di depan publik, seni ilmu pengetahuan mengenai komunikasi lisan yang efektif dengan para pendengar. Masalah lain tentang public speaking menurut Wahyudi (2013), adalah gambaran masyarakat Indonesia belum mampu membedakan antara "speaking" dan "talking". Berbicara sebagai suatu bagian dari sikap profesional seseorang, dan sering dipergunakan terutama oleh orang yang 
menduduki posisi publik serta tanggung jawab yang lebih besar, dia dibimbing oleh fungsi komunikasi public (Carpio, 2005).

Tujuan penelitian ini adalah untuk mengetahui dan menganalisa pesan-pesan politik dalam debat terbuka melalui komunikasi verbal dan nonverbal dengan cara-cara public speaking, serta untuk mengetahui dan menganalisa penguasaan materi dalam debat terbuka para kandidat, persuasi serta membangun opini publik. Serta hasil penelitian ini dapat dimanfaatkan sebagai bahan referensi pada mata kuliah komunikasi politik.

\section{BAHAN DAN METODE}

Jenis penelitian ini adalah deskriptif Kualitatif. Jenis deskriptif bertujuan membuat deskripsi secara sistematis, faktual, dan akurat tentang fakta-fakta dan sifat-sifat populasi atau objek tertentu. Sedangkan penelitian kualitatif bertujuan untuk menjelaskan fenomena dengan sedalam-dalamnya melalui pengumpulan data sedalam-dalamnya (Kriyantono, 2006). Apabila dilihat dari segi pendekatannya penelitian ini dikategorikan penelitian kualitatif. Creswel dalam Patilima (2007), mendefenisikan bahwa pendekatan kualitatif sebagai sebuah proses penyelidikan untuk memahami masalah sosial atau masalah manusia, berdasarkan pada penciptaan gambar holistik yang dibentuk katakata, melaporkan pandangan informan secara terperinci dan disusun dalam sebuah latar ilmiah.

\section{Lokasi dan Rancangan Penelitian}

Penelitian ini dilakukan di Kabupaten Soppeng, salah satu dari 11 daerah di Sulawesi Selatan yang melaksanakan pilkada serentak tahun 2015. Ditetapkannya Kabupaten Soppeng sebagai lokasi penelitian karena hanya di daerah ini yang diikuti 2 (dua) pasangan calon bupati dan wakil bupati. Di samping sebagai daerah yang rawan konflik, juga daerah ini yang tingkat mobilisasi massa yang sangat tinggi.

\section{Sumber Data}

Sumber data penelitian ini adalah sumber data primer, adalah sumber data utama yang dikumpulkan secara langsung dari informan melalui wawancara dan pengamatan merupakan informasi yang terkait dengan fokus yang dikaji. Selanjutnya, data sekunder adalah sumber data pendukung yang diperoleh dari laporan $\neg$ tertulis dan dokumen tertulis yang diperlukan untuk melengkapi data primer yang dikumpulkan.

\section{Teknik Pengumpulan Data}

Teknik pengumpulan data adalah Teknik atau cara-cara yang dapat digunakan oleh peneliti untuk mengumpulkan data melalui, wawancara, observasi dan dokumentasi (Kriyantono, 2006), sebagai berikut: Wawancara mendalam (dept interview) yaitu teknik yang digunakan untuk memperoleh informasi yang lebih mendalam tentang objek dan fokus yang diteliti. Dalam melakukan wawancara diperlukan pedoman wawancara (interview guide). Observasi dalam penelitian ini adalah sebagai teknik pengumpulan data untuk menjaring data pada saat kejadian berlangsung. Teknik dokumentasi adalah mengumpulkan data melalui penelusuran dokumen yang terkait dengan fokus penelitian.

\section{HASIL PENELITIAN}

\section{Public speaking dan penguasaan meteri debat}

Public speaking merupakan kemampuan mutlak yang harus dimilik oleh setiap pemimpin termasuk kandidat dalam suatu pesta demokrasi di tingkat lokal. Kemampuan public speaking yang sederhana, tidak mungkin bisa membawa pengaruh yang kuat pada para konstituennya, karena itu dibutuhkan keterampilan khusus dan teknik tertentu agar public speaking yang dilakukan dapat lebih efektif.

Berdasarkan wawancara bahwa kedua kandidat calon Bupati Soppeng tidak pernah mengikuti pelatihan public speaking. Kemampuan untuk berbicara di depan umum, karena merupakan jabatan di birokrat serta cara otodidak sebagai figur politik. Karena posisinya sebagai publik figur, mengharuskannya untuk selalu tampil dan berbicara yang mengungkapkan ide dan pikiran untuk khalayak.

Debat publik adalah bentuk lain sebuah kampanye politik, di mana beberapa kandidat atau pasangan kandidat mendiskusikan suatu permasalahan. Namun, karena perdebatan itu bukanlah bentuk komunikasi yang 'biasa' dalam keseharian, maka penting untuk mengetahui bagaimana menulis sebuah kerangka perdebatan ini sehingga beberapa argumen dan penjelasan terstruktur dengan baik. 
Berdasarkan penelitian ini bahwa menyusun materi debat pada dasarnya hasil olah pikir dan ide dari berbagai pihak termasuk mengundang beberapa pakar untuk membahasnya dalam sebuah pertemuan. Adapun masukan dari kalangan masyarakat yang sengaja dikumpulkan sebagai bentuk penggalangan aspirasi. Materi yang sifatnya untuk mempersuasi khalayak merupakan materi yang berisi pesanpesan yang bertujuan untuk mempengaruhi pendapat dan kelakuan khalayak. Materi dipergunakan sebagai suatu alat untuk menjankau pemilih cerdas, yang secara psikologi dimanipulasi dan digabungkan ke dalam suatu aliansi kandidat.

\section{Karakter dan kompetensi kandidat dalam suatu debat}

Karakter yang baik diketahui melalui respon yang benar ketika mengalami tekanan, tantangan dan kesulitan. Karakter yang berkualitas adalah sebuah respon yang sudah teruji berkali-kali dan telah berbuahkan kemenangan. Karakter tidak diciptakan, melainkan dibentuk melalui proses yang panjang. Berdasarkan pernyataan informan bahwa karakter suatu pemimpin lokal mestinya sesuai dengan pedoman hidup serta budaya. Tradisi Bugis sebagai latar belakang dari kandidat Bupati Soppeng telah mewarnai kehidupannya dan menghasilkan karakter pada dirinya. Tradisi Bugis secara nyata menempatkan manusia sesuai tempatnya yang dimaknai sebagai suatu upaya penyadaran diri bahwa setiap manusia harus berperilaku dengan cara yang sesuai dengan norma, aturan, dan hukum serta senantiasa mampu mengendalikan diri.

Karakter kandidat Bupati Soppeng tersusun mulai dari petuah atau pesan atau nasehat orang tua serta kearifan lokal yang ada di Soppeng. Salah satu yang dimaksud adalah sebagaimana yang dikonsepkan oleh budaya Bugis yang disebut dengan konsep pappaseng. Salah satu pappaseng yang sering saya ikuti adalah Pappasenna Arung Bila, yang diyakini bahwa pemimpin pemerintahan mengutamakan keluhuran budi pekerti. Semua aspek kehidupan harus berpedoman atau mengacu pada budi dan pekerti luhur.

Kompetensi para kandidat calon Bupati Soppeng didasarkan pada pengetahuan dan pengalaman dalam memimpin suatu arganisasi, yang didukung oleh karakter pribadi serta tutur bahasa yang baik dan jelas bagi audiens. Penguasaan materi oleh kandidat merupakan bentuk dari kompetensinya sebagai pemimpin. Menjadi seorang pemimpin lokal juga harus mempunyai sikap yang digambarkan dalam bentuk kearifan lokal. Hal ini akan menjadi sikap yang mempersuasi khalayak.

\section{Mengelola emosi dan mempersuasi khalayak}

Emosi adalah salah satu unsur ynag membentuk kepribadian manusia yang sangat berharga. Boleh dikata ini unsur yang berdiri sendiri, tapi juga sangat dipengaruhi pola pikir. Emosi merupakan salah satu aspek yang sangat penting dalam kehidupan individu. Berbagai perilaku individu sehari-hari mulai dari yang sederhana hingga yang kompleks banyak dipengaruhi oleh emosi. Bahkan berbagai keputusan penting dalam hidup kita pun banyak dipengaruhi oleh emosi. Oleh karenanya tidak berlebihan jika dikatakan bahwa secara umum, emosi memainkan peranan yang penting dalam kegagalan maupun keberhasilan individu dalam kehidupannya.

Berdasarkan wawancara bahwa para kandidat calon Bupati Soppeng, mengelola emosinya berdasarkan pengalaman yang dimilikinya. Pengalaman tersebut ditempuh dari beberapa latihan, karena emosi sebenarnya dapat dilatih. Emosi yang positif secara personal menghasilkan perasaan yang menyenangkan, sedangkan emosi yang negatif menghasilkan perasaan marah atau kecewa. Mengendalikan emosi dengan belajar mengenali dan menanggapinya dengan cara yang baik dan bermanfaat, bukan dengan mengabaikan atau menekannya.

\section{PEMBAHASAN}

Kebutuhan akan kemampuan public speaking saat ini tidak hanya terbatas pada profesi tertentu, akan tetapi sudah merambah pada bidang politik. Kalangan aktor politik sekali pun, belajar public speaking tentulah akan sangat bermanfaat. Kemampuan public speaking dapat sangat berguna ketika dia diminta tampil dan menyampaikan sebuah presentasi di depan konstituennya. Intinya public speaking ini tidak hanya penting dipelajari oleh mereka yang 
memiliki cita-cita atau impian sebagai politikus saja. Public speaking juga dapat dijadikan peluang politik tanpa modal besar yaitu uang, berupa bisnis modal dengkul atau bisa juga disebut sebagai "modal mulut".

Kemampuan berbicara di depan umum merupakan aset dan investasi berharga serta menguntungkan khususnya kalangan politikus. Seorang yang mampu berbicara dengan baik di depan khalayak, menyampaikan pesannya yang baik pula. Pembicara yang baik akan mudah menyampaikan pandangannya dan pasti didengar oleh kawan bicaranya. Public speaking memberikan begitu banyak kesempatan bagi politikus untuk meningkatkan kesuksesan sebagai talenta kepemimpinan.

Kompetensi adalah seperangkat pengetahuan, keterampilan, dan perilaku yang harus dimiliki, dihayati, dikuasai, dan diaktualisasikan oleh kandidat. Kandidat berhak memperoleh kesempatan untuk meningkatkan kompetensinya, memperoleh pelatihan berbicara di depan umum. Latihan atau mengikuti pelatihan merupakan kunci untuk menwujudkan peningkatan kompetensi para kandidat. Melatih berbicara di depan umum merupakan kegiatan ideal dalam mengembangkan bakat dan penalaran kandidat. Berdebat mengajarkan kemampuan berbicara secara bertanggung jawab dan kemampuan berpikir kritis.

Kompetensi merupakan kemampuan dan kecakapan yang harus dicapai oleh kandidat sebagai pendebat. Kandidat diharuskan untuk mampu mencapai kompetensi-kompetensi maka dapat dikatakan kandidat tersebut mampu menguasai materi dan berhasil dalam debat. Hal tersebut menempatkan kompetensi sebagai sesuatu yang dituju atau dicapai sehingga kompetensi juga merupakan tujuan.

Penguasaan kompetensi juga mampu membentuk pribadi kandidat yang menjadikan adanya keselarasan antara pikiran, perkataan dan perbuatan. Dengan adanya banyak aspek dalam masing-masing kompetensi menjadikan kompetensi merupakan sebuah kecakapan yang dikuasai dan bermanfaat bukan hanya ketika berdebat namun juga dapat berguna dalam kegiatan sehari-hari. Dengan kemampuan yang didapat dari penguasaan kompetensi juga nantinya dapat bermanfaat untuk diaplikasikan pada karir politiknya.
Emosi merupakan sebuah pengalaman rasa, para pendebat merasakan adanya emosi, dan tidak sekedar memikirkannya. Biasanya diikuti dengan pikiran yang ada hubungannya dengan perkataan tersebut, perubahan psikis, dan hasrat untuk melakukan sesuatu. Bila ada petanyaan dari moderator atau beberapa sanggahan dari lawan debat, maka psikis pendebat mengalami perubahan. Emosi bisa mengalihkan perhatian dari persoalan pokok yang akan dibicarakan. Emosi bisa menghancurkan hubungan. Emosi bisa mengeksploitasi kita. Sebaliknya, emosi positif bisa mempermudah terpenuhinya beberapa kepentingan khususnya dalam mempersuasi khalayak. Emosi positif dapat mempererat hubungan antara pendebat dengan audiens.

\section{KESIMPULAN DAN SARAN}

Debat adalah pembahasan dan pertukaran pendapat mengenai sesuatu hal dan saling memberikan alasan untuk mempertahankan pendapat masing-masing kandidat. Aktivitas debat politik dapat membawa implikasi terhadap pengetahuan, sikap, perilaku, serta isu-isu yang berkembang di dalam masyarakat. Debat politik ditujukan untuk memberikan bekal pengetahuan tentang visi misi dan program kerja kandidat kepada pemilih. Dengan pengetahuan tersebut, masyarakat dapat memilih calon pemimpin secara tepat dan beralasan, sehingga masyarakat bisa menentukan sikap politik secara berimbang dan objektif. Melalui debat publik, para kandidat dapat menyampaikan gagasan dan visi misi yang dikemas melalui pesan-pesan politik untuk tujuan membentuk dan memengaruhi opini, sikap dan sampai pada pengambilan keputusan memilih. Dampak komunikasi politik tersebut bisa berupa perubahan-perubahan opini, persepsi, sikap bahkan sampai pada perubahan dalam pengambilan keputusan pemilih terhadap suatu kandidat. Debat publik bertujuan untuk mempersuasi dan memotivasi pemilih untuk memilih kandidat tertentu. Disamping tujuan utamanya adalah pendidikan politik dan senantiasa mengedepankan informasi tentang kandidat. Debat publik yang tidak memanfaatkan retorika, dapat menimbulkan kebosanan sehingga perhatian khalayak (audiens) tidak tercurah pada materi yang disampaikan oleh kandidat. Oleh sebab itu sebaiknya para kandidat memanfaatkan 
retorika dalam proses debat, disatu pihak ia akan disenangi audiens, dan dilain pihak kandidat akan berhasil sebagai pemimpin yang legal dari hasil keterpilihannya.

\section{DAFTAR PUSTAKA.}

Cangara. (2014). Pengantar Ilmu Komunikasi. Jakarta: Rajawali Pers.

Cangara. (2015). Komunikasi Politik : konsep, teori dan strategi. Jakarta: Rajawali Press.

Carpio. (2005). Privat and Public Speaking. Jakarta: Yayasan Obor Indonesia.

Hasrullah. (2014). Opium Politik \& Dramaturgi. Jakarta: Pranada Media.

Hidajat. (2006). Public Speaking \& Teknik Presentasi. Yogyakarta: Graha Ilmu.

Kaid. (2015). Handbook Penelitian Komunikasi Politik. Bandung: Penerbit Nusa Media.
Kriyantono. (2006). Teknis Praktis Riset Komunikasi Jakarta: Kencana.

Littlejohn et al. (2014). Teori Komunikasi. Jakarta: Salemba Humanika.

Mulyana. (2014). Komunikasi Politik Politik Komunikasi : Membedah visi dan gaya komunikasi praktisi politik. Bandung: Remaja Rosdakarya.

Patilima. (2007). Metode Penelitian Kualitatif. Jakarta: Alfabeta.

Rauf et al. (1993). Indonesia dan Komunikasi Politik. Jakarta: Gramedia Pustaka Utama.

Ruben. (2013). Komunikasi dan Perilaku Manusia. Jakarta: RajaGrafindo Persada.

Subiakto. (2014). Komunikasi Politik, Media, dan Demokrasi. Jakarta: Kencana.

Wahyudi. (2013). The Secret of Public Speaking era Konseptual. Jakarta: Bbc Publisher. 